\title{
Effect of Different Combinations of Plant Growth Regulators on in vitro Propagation of Yam (Dioscorea Species)
}

\author{
Obssi Dessalegn (Corresponding author) \\ Department of biotechnology, Gondar University, Gondar, Ethiopia \\ Tel: 251-922-342-852Ｅ-mail: dobssi@gmail.com
}

Kassahun Bantte

Department of Plant biotechnology, Jimma University, Jimma, Ethiopia

\author{
Mulugeta Diro
}

Capacity building for scaling up of evidence-based best practices in agricultural production in Ethiopia (CASCAPE) project, Addis Ababa

Received: March 16, 2015 Accepted: April 18, 2015 Published: April 20, 2015

Doi: 10.5296/jab.v3n2.7471 URL: http://dx.doi.org/10.5296/ jab.v3n2.7471

\begin{abstract}
Seed tubers are expensive, bulky and the multiplication rate in the field is very low. Shortage of seed tubers for planting is one of the major constraints for yam production in Ethiopia. No information is available on micropropagation of Dioscorea spp. in Ethiopia. To overcome such problem, the current study was, initiated to optimize type and concentration of plant growth regulators for shoot multiplication and rooting. Shoot multiplication and rooting in vitro were carried out using a completely randomized design with five replications. For shoot multiplication, shoots initiated from nodal cuttings were treated with BAP in combination with NAA. For rooting, the micro-shoots were transferred to $1 / 2 \mathrm{MS}$ media containing NAA and IBA. Data on number of shoots per explant, roots per shoot and related growth parameters were recorded and statistically analyzed. The results showed that MS media supplemented with $1.5 \mathrm{mg} / \mathrm{BAP}+0.15 \mathrm{mgl}^{-1} \mathrm{NAA}$ gave an average of $6.40 \pm 0.28$ shoots per explant with a mean shoot length of $2.0 \pm 0.11 \mathrm{~cm}$. MS supplemented with BAP $\left(1.0 \mathrm{mg}^{-1}\right)$ and NAA $\left(0.15 \mathrm{mg} \mathrm{l}^{-1}\right)$ gave $5.40 \pm 0.28$ with a mean shoot length of $1.84 \pm 0.20 \mathrm{~cm}$. Plantlets
\end{abstract}


grown on half strength MS media supplemented with $2.0 \mathrm{mg}^{-1} \mathrm{NAA}$ and $0.5 \mathrm{mg}^{-1}$ IBA produced $5.7 \pm 0.27$ roots per plantlet and an average root length of $4.63 \pm 0.23 \mathrm{~cm}$. Thus MS $+1.5 \mathrm{mgl}^{-1} \mathrm{BAP}+0.15 \mathrm{mg} \mathrm{l}^{-1} \mathrm{NAA}$ and $1 / 2 \mathrm{MS}+2.0 \mathrm{mg} \mathrm{l}^{-1} \mathrm{NAA}+0.5 \mathrm{mgl}^{-1} \mathrm{IBA}$ is the best hormone combination for shoot multiplication and in vitro rooting respectively.

Keywords: Dioscorea species, Micropropagation, Nodal cutting, Yam

\section{Introduction}

Yam belongs to the genus Dioscorea in the family Dioscoreaceae. The family is believed to be among the earliest angiosperms and probably originated in Southeast Asia (Coursey, 1976). It is a traditional crop that has long been cultivated in Southern, Western and Southwestern parts of Ethiopia as staple or co-staple with enset (Ensete ventricosum), cereals, and other root and tuber crops (Westphal, 1975; Edwards, 1991; Mie'ge \& Demissew, 1997; Wilkin, 1998; Gemeda, 2000). About 600 species of yam have been recorded (Coursey, 1967; Govaerts et al., 2007), but the major cultivated ones are D. alata, D. bulbifera, D. cayenensis, D. esculenta, D. opposita-japonica, D. nummularia, D. pentaphylla, D. rotundata and D. trifida (Boussalem et al., 2006; Lebot, 2009).

The dominant region for yam production in the world is West Africa, where about 48 million tons (about 93\% of the world's production) produced on 4 million hectares annually (Hahn, 1995; Wilkin, 2001; Mulaama, 2004; FAO, 2009). In Ethiopia, the total annual production of yam was estimated at about 277,000 metric tons from an area of about 68,000 ha, corresponding to a yield of about 4 tons per hectare (FAO, 2009). However, Gemeda (2000) reported that yam is more productive than the other tuber crops in the area, with an estimated yield of about 20 tons per hectare. Expanded production of yams in new areas or where it is produced in limited quantities in other parts of the tropics including Ethiopia would contribute significantly to food security, improved health and increased income (Westphal, 1975; Mie' ge \& Demissew, 1997; Lebot, 2009; Asiedu \& Sartie, 2010).

As the crop is adapted to dry season planting (mainly at the onset of the dry season in October) early harvests in May fill a seasonal gap in food supply in Ethiopia (Tamiru et al., 2005; Tamiru, 2006; Tamiru, 2008). Their storage organs (underground and/or aerial tubers) are sources of proteins, fats, and vitamins for millions of people in Africa (Hahn et al., 1987; Lebot, 2009). In addition, Dioscorea is a well-known edible and traditional medicinal plant, since the genus is rich in steroidal saponins and as sources of biologically active compounds in pharmaceutical industries (Wang et al., 2006; Kole, 2011).

Yam is propagated from seed tubers or sections of tubers and corms. Seed tubers are expensive, accounting sometimes for about as much as $50 \%$ of total variable cost (Manyong, 2000); they are bulky to transport and have extended dormancy period. The multiplication ratio in the field is very low (less than 1:10) compared, for instance, to some cereals $(1: 300)$ (Balogun, 2009). Traditionally farmers obtain seed tubers by selecting small tubers (e.g. 200$500 \mathrm{~g}$ ) from each harvest (unfortunately these are often those produced by diseased plants by nematodes and Insects such as yam shoot beetle, often interact with fungi (Botryodiplodia, Fusarium) and bacteria (Erwinia spp.) to damage tubers in the field and in storage (Aighewi et al., 2003a; Lebot, 2009). Diehl's (1982) survey report in Nigeria also showed shortage of planting material (owing to low reproductive rate) which may lead to future decline in yam 
production.

In Ethiopia there is shortage of seed tubers for planting, lack of formal seed supply system and specialization in the production of yam planting-materials (Tamiru et al., 2005; Tamiru et al., 2008). Farmers mostly rely on their own planting-materials saved from the previous cropping season; some farmers partly meet their demand for seed tubers through purchases from local markets or exchanges with neighbors. This has led to a decrease in production (Tamiru et al., 2008) due to insufficient quantity and poor quality of planting material.

In addition, farmers often encounter shortages of yam planting material, especially following droughts and disease epidemics. Productivity is hampered by pests and diseases and the limited availability and high cost of planting materials (Balogun et al., 2004). So, some farmers keep a reserve batch of seed yams (up to a third of the quantity planted) for replacement of seeds that do not germinate. Poor quality planting materials that germinate tend to carry disease and pest (viruses, fungi, nematodes and insects) from the storage barns to the field the next season resulting in low tuber yields, followed by poor shelf life (Asiedu \& Sartie, 2010; Ghosh et al., 1988).

To overcome such problems and increase production, conventional methods such as partial sectioning, layering, vine rooting and minisett technique have been used to produce high amount of planting material (Okoli et al., 1982; Wilson, 1989). Minisett technique has significantly increased propagation rates, but it has been associated with less uniform and poor rate of sprouting when applied to white yam (Okoli et al., 1982). The partial sectioning requires considerable manpower for the repeated examining and digging out of tubers to excise sprouted sections for field planting. In case of vine rooting technique, either tubers did not develop due to early senescence of rooted vines (Acha et al., 2004), or small tubers are produced when applied to D. rotundata (Okoli et al., 1982). The layering technique is unsuitable for farm use due to rigorous procedures involved (Acha et al., 2004) and it is genotype specific (Acha et al., 2004; Shiwachi et al., 2005b).

So, other methods of rapid propagation such as micropropagation have been developed (Balogun et al., 2004) including production of microtubers from plantlets ïn vitro (Aighewi et al., 2003b; Feng et al., 2007). Micropropagation of yam offers the distinct advantage of large scale multiplication of high quality, clonally propagated planting materials ( $\mathrm{Ng}, 1988$; Asha \& Nair, 2007). It provides many advantages over conventional methods including: (1) it enables mass propagation of specific species, (2) it helps to produce pathogen-free planting material, (3) it enables clonal propagation of parental stock for hybrid seed production, and (4) it enables year-round nursery production (Hartmann et al., 2002).

In vitro propagation has been implemented for many Dioscorea species, such as $D$. rotundata (Balogun et al., 2006), D. nipponica Makino. (Chen et al., 2007), Dioscorea esculenta (Lour.) Burk, (Kharat et al., 2008), D. hispida (Behera et al., 2008), Dioscorea alata L.cv. Hatikhujia (Behera et al., 2010), wild yam (Dioscorea wightii), Mahesh et al., 2010, Dioscorea fordii (Yan et al., 2011) and they reported that the response of yam (Dioscorea spp.) towards in vitro propagation depends on the presence and absence of auxin and cytokinin.

However, a protocol developed for one specific species of plant is not reproducible when applied to other genotypes even within the same species i.e. each genotype has its own 
requirements in all stages of in vitro propagation (Omar \& Aouine, 2007). Likewise the response of yam in vitro is genotype specific (Balogun et al., 2004; Ahanhanzo et al., 2010). Despite its importance especially for food security, no information is available on vitro propagation of yam variety Aw-004/00. The variety is believed to be widely distributed in Southern and Southwestern part of Ethiopia and it is the only released variety of yam in the country. This variety was released by Hawassa Agricultural Research Center in 2010. It is characterized by high yield ( $25 \mathrm{t} / \mathrm{ha}$ on farmers' field) and it is preferred by farmers (MoA, 2010). The current study was, therefore, initiated with the following objectives:

$>$ To optimize concentration of BAP in combination with NAA for shoot multiplication

$>$ To determine the optimum concentration and combination of NAA and IBA for rooting.

\section{Materials and Methods}

\subsection{Planting Materials}

Yam variety Aw-004/00 (Dioscorea spp.) was used as a source of explant. The variety was obtained from Hawassa Agricultural Research Center.

\subsection{Study Area Description}

These experiments were carried out in the tissue culture laboratory of Jimma University College of Agriculture and Veterinary Medicine (JUCAVM), during 2011-2012. The study area is located $363 \mathrm{~km}$ south west of Addis Ababa at $7^{\circ} 46^{\prime} \mathrm{N}$ latitude and $36^{\circ} 0^{\prime} \mathrm{E}$ longitudes. The mean annual rainfall is $1529.5 \mathrm{~mm}$ and the mean annual max/min temperature is 26.2/11.3 ${ }^{\circ} \mathrm{C}$ (IAR, 1997).

\subsection{Mother Plant and Explants Preparation}

The seedlings of Aw-004/00 variety were established and grown in the greenhouse and they were grown until they form 15 or more nodal segments per plantlet. The growing nodal segments were cut from the seedling and prepared by removing extra leaf sheaths and then taken to laboratory for surface sterilization.

Explants (5-10 cm nodal segments) were washed under running tap water and then treated with $0.3 \%$ a fungicide (Kocide) solution for 20-30 minutes. Then, the explants were treated with mercuric chloride $\left(0.1 \% \mathrm{HgCl}_{2}\right.$ for 5 minutes) solution followed by $70 \%$ ethanol for 1 min. The explants were then thoroughly rinsed three times with sterile distilled water and the explants were reduced to one node size (about 1-2 $\mathrm{cm}$ ) and placed on MS media containing 1 $\mathrm{mg} / \mathrm{l}$ BAP under aseptic condition in laminar flow cabinet, which has been used as initiation media for yam (Mwirigi et al., 2010; Chen et al., 2007). The explants started initiation within 4-8 days after culturing.

\subsection{Culture Medium and Condition}

Murashige and Skoog (MS) (1962) basic media was used for all experiments (Appendix 3). Surface sterilized explants were cultured in culture jar containing $30-40 \mathrm{ml}$ media supplemented with $1 \mathrm{mgl}^{-1}$ BAP and one explant per jar was used for shoot initiation. Then the initiated explants were transferred to glass jars with a capacity of $350 \mathrm{ml}(560 \times 355 \mathrm{~mm})$ containing 50-60 ml media for shoot multiplication. Similarly $1 / 2 \mathrm{MS}$ media were prepared and $30-40 \mathrm{ml}$ media were poured into pre sterilized glass culture jars with a capacity of 120 $\mathrm{ml}$ for rooting. 


\section{Macrothink

All the aseptic activities such as surface disinfection of explants, preparation and inoculation of explants and subsequent sub-culturing were carried out in the laminar air flow cabinet. The working table of laminar air flow cabinet and spirit lamp were sterilized by swabbing with $70 \%$ ethanol. All the required materials like media, spirit lamp, lighter and glass ware were kept under the clean laminar air flow hood. The cultures were maintained at 16 hour photoperiod, temperature of $25 \pm 2{ }^{\circ} \mathrm{C}$, humidity of $60-70 \%$ and light intensity of $1500-2000$ lux $\left(20-27 \mu \mathrm{mol} \mathrm{m} \mathrm{s}^{-1}\right)$ provided by florescent light.

\subsection{Treatments and Experimental Design}

All the experiments were laid down in a completely randomized design (CRD) with five replications (five jars each with three explants, a total of 15 explants for multiplication and each with two shoots, a total of 10 shoots per treatment for rooting were used).

\subsubsection{Experiment 1: Effects of BAP and NAA Combination on Shoot Multiplication}

In this experiment, MS medium containing 3\% sucrose, $0.8 \%$ agar, and different levels of BAP and NAA was used to test the effects of different plant growth regulators on shoot multiplication. Four concentrations of $\operatorname{BAP}\left(0.5,1,1.5\right.$ and $\left.2 \mathrm{mg}^{-1}\right)$ and NAA $(0,0.15,0.25$, and $0.5 \mathrm{mgl}^{-1}$ which is similarly NAA concentration used by Kharat et al. (2008)) in $4 \times 4$ factorial combinations were used. Basal medium (without plant growth regulators) was included as a control.

\subsubsection{Experiment 2: Effect of NAA and IBA Combinations on in vitro Rooting}

Under this experiment, the effect of auxin types and concentrations on rooting of in vitro shoots were studied. Accordingly, $1 / 2$ MS medium supplemented with five concentrations of IBA $\left(0,0.5,1,1.5,2 \mathrm{mgl}^{-1}\right)$ and five concentrations of NAA $\left(0,0.5,1,1.5,2 \mathrm{mgl}^{-1}\right)$ in $5 \times 5$ factorial combinations were tested.

\subsubsection{Acclimatization}

Plantlets with three to four leaves were transplanted to plastic pots filled with sterilized nursery medium in equal ratio of manure, forest soil and sand (Figure 1) after agar is completely removed from the roots by washing under tap water and then covered with polyethylene plastic sheet in the greenhouse. The plants were sprayed three times with water every (morning, midday and night) for a period of three weeks. After four weeks, percent of acclimatized seedlings or plantlets were recorded. 


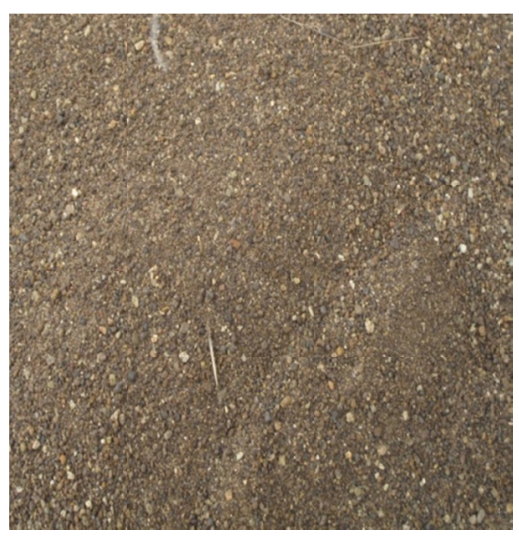

A

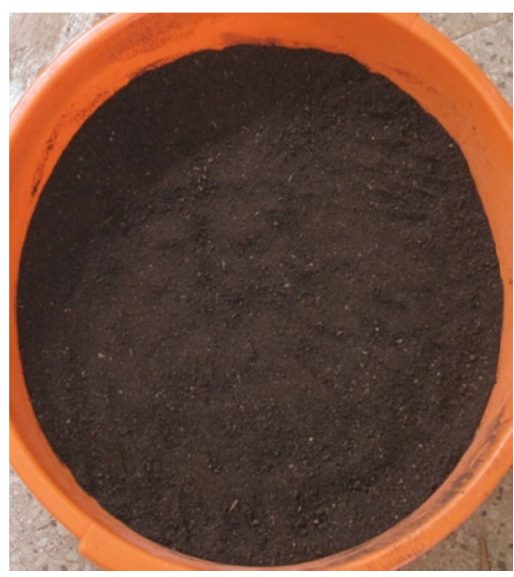

$\mathrm{D}$

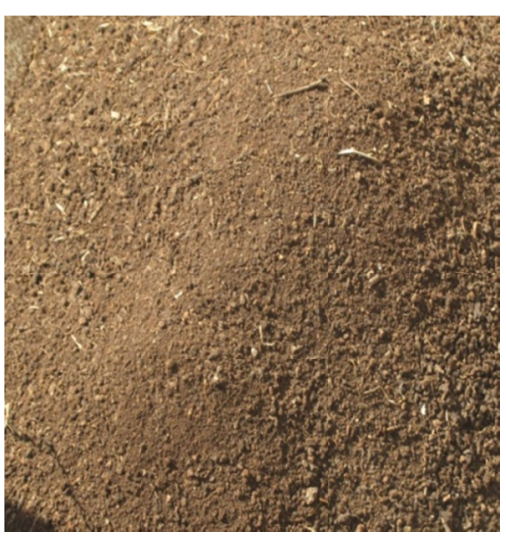

B

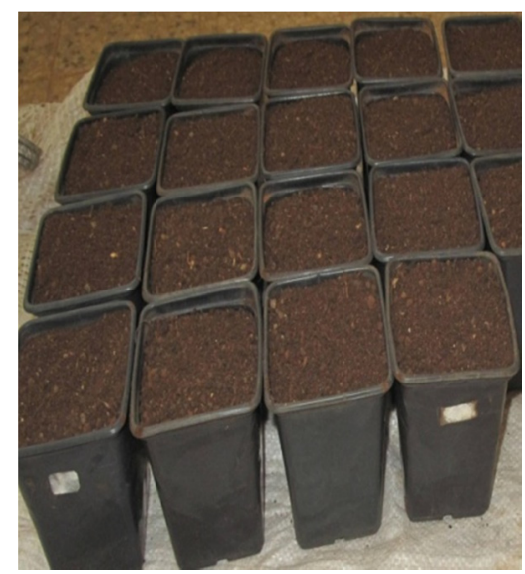

E

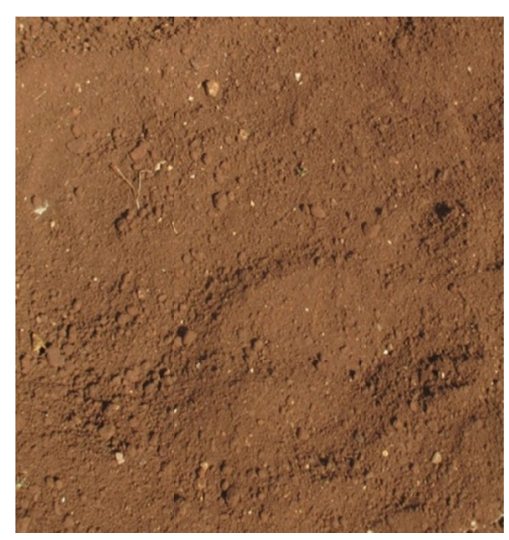

$\mathrm{C}$

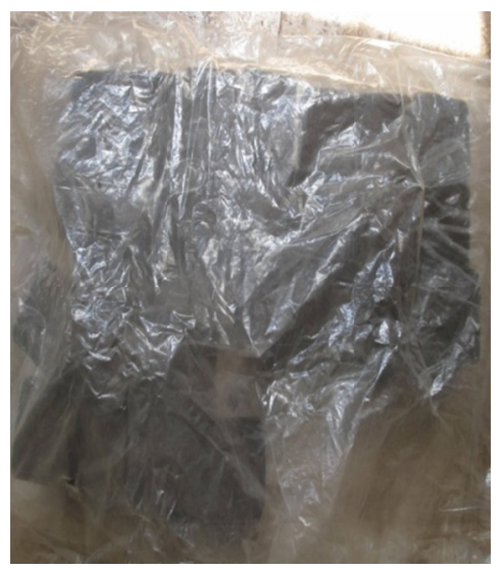

F

Figure 1. Soil medium preparation for acclimatization. Sand (A). Dried and decomposed manure (B). Forest soil (C). Sterilized 1:1:1 combination of sand: manure: soil (D\&E).

Plantlets covered by plastics soon after their transfer on to the soil (F)

\subsection{Data Collected}

Data were collected on growth parameters of in vitro generated plantlets after 40-45 days of culturing on multiplication media and four weeks after culturing on rooting media. Number of nodes, number of shoots, and number of leaves were counted from five jars each containing three explants, a total of 15 explants. Number of roots and root length were counted from five jars each with 2 shoot, from a total of 10 shoots per treatment. The average number of nodes/explant, average number of shoots/explant, mean shoot length, average number of leaf/explant, average number of roots/shoot and mean of root length were computed from the collected data.

\subsection{Data Analysis}

The collected data were analyzed using SAS (version 9.2) software (SAS Institute Inc. 2008). The data were subjected to analysis of variance (ANOVA) and mean separation was done using procedure of REGWQ for significant means at a probability of $5 \%$. 


\section{Results and Discussion}

The present study was conducted to investigate optimal concentrations and combinations of plant growth regulators in the medium for micropropagation in yam via nodal culture. The results obtained are presented and discussed as follows:

\subsection{Effects of BAP and NAA Combination on Shoot Multiplication}

Analysis of variance showed that BAP and NAA combinations were highly significantly different $(p<0.0001)$ for shoot multiplication (Appendix 1). The response of nodal explants cultured on different shoot multiplication media is presented in Table 1. The results showed that culture medium devoid of plant growth regulators (control) failed to stimulate any shoot multiplication in the cultured explants within a period of five weeks. MS media supplemented with growth regulators (BAP in combination with NAA) produced better results in terms of shoots /explant, average shoot length and average number of nodes per explant.

Among the combination tested, $1.5 \mathrm{mgl}^{-1} \mathrm{BAP}+0.15 \mathrm{mgl}^{-1} \mathrm{NAA}$ resulted in the highest response in which an average of $6.40 \pm 0.28$ shoots per explant with a mean shoot length of $2.0 \pm 0.11 \mathrm{~cm}$ was obtained (Table 1; Figure 2A). The second best shoot multiplication (5.40 \pm 0.28 shoots per explants and mean shoot length of $1.84 \pm 0.20 \mathrm{~cm})$ was obtained on MS medium supplemented with BAP $\left(1.0 \mathrm{mgl}^{-1}\right)+\mathrm{NAA}\left(0.15 \mathrm{mgl}^{-1}\right)$ (Figure 2B). MS medium supplemented with BAP $\left(1.5 \mathrm{mgl}^{-1}\right)+$ NAA $\left(0.25 \mathrm{mgl}^{-1}\right)$ resulted in $4.33 \pm 0.34$ shoots/explant with a shoot length of $4.0 \pm 0.12$ where number of shoots per explant is significantly lower than that of the first two combinations of plant growth regulators whereas the shoot length is significantly improved (Table 1, Figure 3A).

The dependency of cultured nodal explants of Dioscorea spp. on the presence or absence of cytokinin and auxin for shoot multiplication has already been established (Adeniyi et al., 2008; Mwirigi et al., 2010). This has also been recently reported in the case of micropropagation of other yams like D. composite (Alizadeh et al., 1998), D. oppositifolia (Behera et al., 2009), Dioscorea alata (Behera et al., 2010). In this experiment, on MS medium supplemented with $1.5 \mathrm{mgl}^{-1}$ BAP alone, 4.33 shoots per explant was obtained. When $0.15 \mathrm{mgl}^{-1} \mathrm{NAA}$ was added in the presence of $1.5 \mathrm{mgl}^{-1} \mathrm{BAP}$, a significant improvement in the number of shoots per explant (6.4,) was recorded showing the existence of interaction effect between BAP and NAA. This result confirms the reports of Chen et al. 2007 and Adeniyi et al. (2008) where media supplemented with BAP and NAA combination induced best shoot multiplication, indicating that the effectiveness of each of the phytohormone in inducing shoots multiplication was influenced by the presence or absence of the other. 
Table 1. Shoot multiplication in nodal explants of Dioscorea spp. cultured on MS medium supplemented with various concentrations of BAP and NAA

\begin{tabular}{|c|c|c|c|c|c|}
\hline \multicolumn{2}{|c|}{$\begin{array}{l}\text { Treatments } \\
\left(\mathrm{mg}^{-1}\right)\end{array}$} & \multirow{2}{*}{$\begin{array}{l}\text { Mean No of } \\
\text { shoots/explant } \\
\pm \text { S.D. }\end{array}$} & \multirow{2}{*}{$\begin{array}{l}\text { Mean } \\
\text { length } \\
\pm \text { S.D. }\end{array}$} & \multirow{2}{*}{$\begin{array}{l}\text { Mean No of } \\
\text { nodes/explant } \\
\pm \text { S.D. }\end{array}$} & \multirow[t]{2}{*}{$\begin{array}{l}\text { Mean } \quad \text { No of } \\
\text { leaf/explant } \pm \text { S.D. }\end{array}$} \\
\hline BAP & NAA & & & & \\
\hline 0 & 0 & $0.00^{\mathrm{h}} \pm 0.0$ & $0.00^{\mathrm{i}} \pm 0.00$ & $0.00^{\mathrm{h}} \pm 0.00$ & $0.00^{\mathrm{h}} \pm 0.00$ \\
\hline 0.5 & 0 & $2.60^{\mathrm{gf}} \pm 0.28$ & $1.07^{\mathrm{fg}} \pm 0.08$ & $5.2^{\mathrm{ef}} \pm 0.56$ & $1.16(14.2)^{\mathrm{cd}} \pm 0.13$ \\
\hline 0.5 & 0.15 & $4.53^{\mathrm{c}} \pm 0.38$ & $1.42^{\mathrm{e}} \pm 0.16$ & $6^{\mathrm{d}} \pm 0.53$ & $1.16(13.87)^{\mathrm{cd}} \pm 0.11$ \\
\hline 0.5 & 0.25 & $2.20^{\mathrm{g}_{ \pm}} \pm 0.30$ & $1.61^{\mathrm{de}} \pm 0.12$ & $6.20^{\mathrm{d}} \pm 0.56$ & $1.26(17.13)^{\mathrm{abc}} \pm 0.01$ \\
\hline 0.5 & 0.5 & $0.00^{\mathrm{h}} \pm 0.0$ & $0.00^{\mathrm{i}} \pm 0.00$ & $0.00^{\mathrm{h}} \pm 0.00$ & $(0.00)^{\mathrm{h}_{1}} \pm 0.00$ \\
\hline 1 & 0 & $3.60^{\mathrm{d}} \pm 0.30$ & $1.45^{\mathrm{e}} \pm 0.19$ & $6.00^{\mathrm{d}} \pm 0.53$ & $1.18(7.87)^{\mathrm{bcd}} \pm 0.03$ \\
\hline 1 & 0.15 & $5.40^{\mathrm{b}} \pm 0.28$ & $1.84^{\mathrm{cd}} \pm 0.20$ & $7.00^{\mathrm{c}} \pm 0.23$ & $1.2(10.2)^{\mathrm{abcd}} \pm 0.08$ \\
\hline 1 & 0.25 & $2.67^{\mathrm{efg}} \pm 0.24$ & $2.6^{\mathrm{b}} \pm 0.15$ & $7.53^{\mathrm{cb}} \pm 0.30$ & $1.3(11.6)^{\mathrm{ab}} \pm 0.03$ \\
\hline 1 & 0.5 & $3.47^{\mathrm{d}} \pm 0.3$ & $1.06^{\mathrm{fg}} \pm 0.18$ & $3.40^{\mathrm{f}} \pm 0.28$ & $0.91(7.67)^{g_{ \pm}} \pm 0.06$ \\
\hline 1.5 & 0 & $4.33^{c} \pm 0.24$ & $1.75^{\mathrm{cd}} \pm 0.12$ & $7.07^{c} \pm 0.43$ & $1.2(14.94)^{\mathrm{abcd}} \pm 0.02$ \\
\hline 1.5 & 0.15 & $6.40^{\mathrm{a}} \pm 0.28$ & $2.0^{\mathrm{c}} \pm 0.11$ & $7.8^{\mathrm{b}} \pm 0.18$ & $1.26(17.27)^{\mathrm{abc}} \pm 0.03$ \\
\hline 1.5 & 0.25 & $4.33^{\mathrm{c}} \pm 0.34$ & $4.0^{\mathrm{a}} \pm 0.12$ & $9.6^{\mathrm{a}} \pm 0.28$ & $1.32(19.67)^{\mathrm{a}} \pm 0.01$ \\
\hline 1.5 & 0.5 & $3.20^{\mathrm{de}} \pm 0.30$ & $1.37^{\mathrm{e}} \pm 0.13$ & $4.6^{\mathrm{f}} \pm 0.28$ & $0.91(7.13)^{\mathrm{g}} \pm 0.05$ \\
\hline 2 & 0 & $3.27^{\mathrm{d}} \pm 0.28$ & $0.77^{\mathrm{h}} \pm 0.13$ & $3.8^{\mathrm{g}} \pm 0.38$ & $0.95(14)^{\mathrm{fg}_{ \pm}}{ } .03$ \\
\hline 2 & 0.15 & $4.13^{\mathrm{c}} \pm 0.38$ & $1.104^{\mathrm{f}} \pm 0.21$ & $5.87^{\mathrm{de}} \pm 0.38$ & $1.05(14.93)^{\mathrm{ef}} \pm 0.05$ \\
\hline 2 & 0.25 & $3.53^{\mathrm{d}} \pm 0.38$ & $1.64^{\mathrm{de}} \pm 0.12$ & $6^{\mathrm{d}} \pm 0.53$ & $1.1(18.67)^{\mathrm{de}_{ \pm}} \pm 0.05$ \\
\hline 2 & 0.5 & $3.07^{\mathrm{def}} \pm 0.36$ & $0.8^{\mathrm{gh}} \pm 0.22$ & $3.67^{\mathrm{g}} \pm 0.24$ & $0.94(7.13)^{\mathrm{g}_{ \pm}} \pm 0.05$ \\
\hline $\mathrm{CV} \%$ & & 8.3 & 9.7 & 6.9 & 5.4 \\
\hline
\end{tabular}

(a-i means having the same letters in a column were not significantly different at $\mathrm{P}<0.05$ level. S.D.-Standard deviation of mean, means in the brackets were the actual data while the one outside of the brackets were transformed data using log transformation)

It has been also reported that when Kenyan yam was cultured on media with BAP supplement alone, a limited proliferation of explants with an average of 1.1 shoots per cultured explant was observed while addition of $0.02 \mathrm{mgl}^{-1}$ NAA produced an average of 2.1 shoots per explant (Mwirigi et al., 2010). 


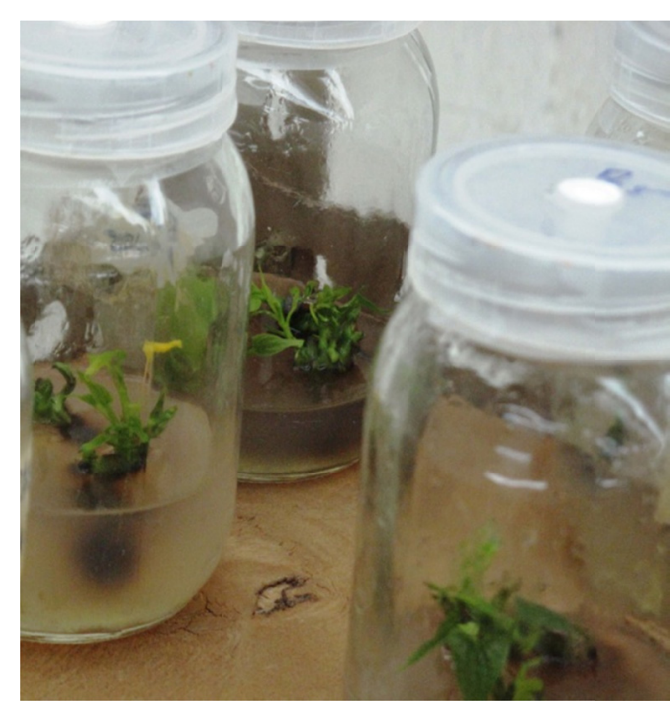

A

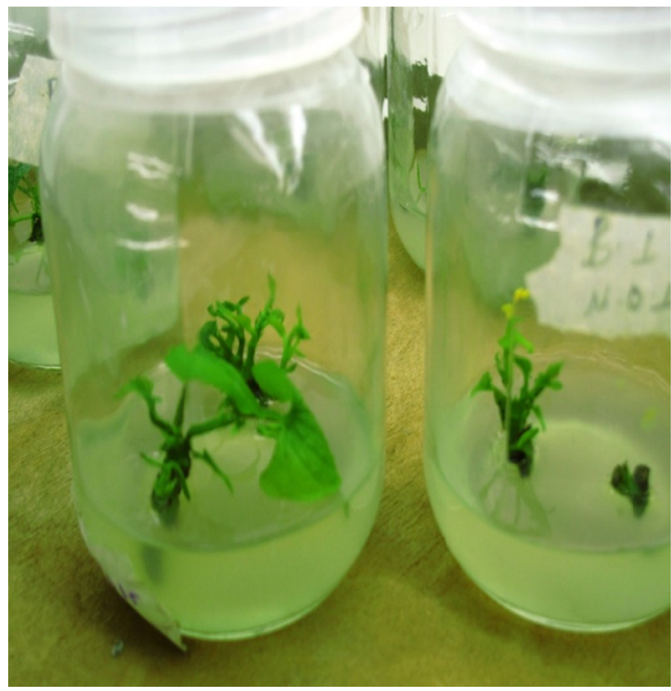

B

Figure 2. Shoot multiplication. Shoot multiplied on BAP $1.5 \mathrm{mgl}^{-1}$ \& NAA 0.15(A). Medium supplemented with $1 \mathrm{mgl}^{-1} \mathrm{BAP} \& 0.15 \mathrm{mgl}^{-1} \mathrm{NAA}(\mathrm{B})$

In this study only single cytokinin was found to be used for shoot multiplication but some authors suggested that the combination of two cytokinins with auxin were needed for producing higher number of multiple shoots. Behera and his coworkers in 2009 obtain an average of $10.5 \pm 0.51$ shoots on MS+ Kinetin $\left(2.0 \mathrm{mgl}^{-1}\right)+\mathrm{BAP}\left(1.0 \mathrm{mgl}^{-1}\right)+\mathrm{NAA}\left(0.5 \mathrm{mgl}^{-1}\right)$ with ascorbic acid $100 \mathrm{mgl}^{-1}$ followed by MS + Kinetin $\left(1.5 \mathrm{mgl}^{-1}\right)+\mathrm{BAP}\left(1.0 \mathrm{mgl}^{-1}\right)+\mathrm{NAA}$ $\left(0.5 \mathrm{mgl}^{-1}\right)+100 \mathrm{mgl}^{-1}$ ascorbic acid where $5.5 \pm 0.43$ shootlets were obtained. In 2010 the same authors reported $6.5 \pm 0.42$ shootlets on Kinetin $\left(1.5 \mathrm{mgl}^{-1}\right)+$ BAP $\left(1.0 \mathrm{mgl}^{-1}\right)+$ NAA $\left(0.5 \mathrm{mgl}^{-1}\right)+100 \mathrm{mg} \mathrm{l}^{-1}$ ascorbic acid with different yam species which is completely different from present study in terms of methodology but similar outcome with best result of the present study. 


\section{Macrothink}
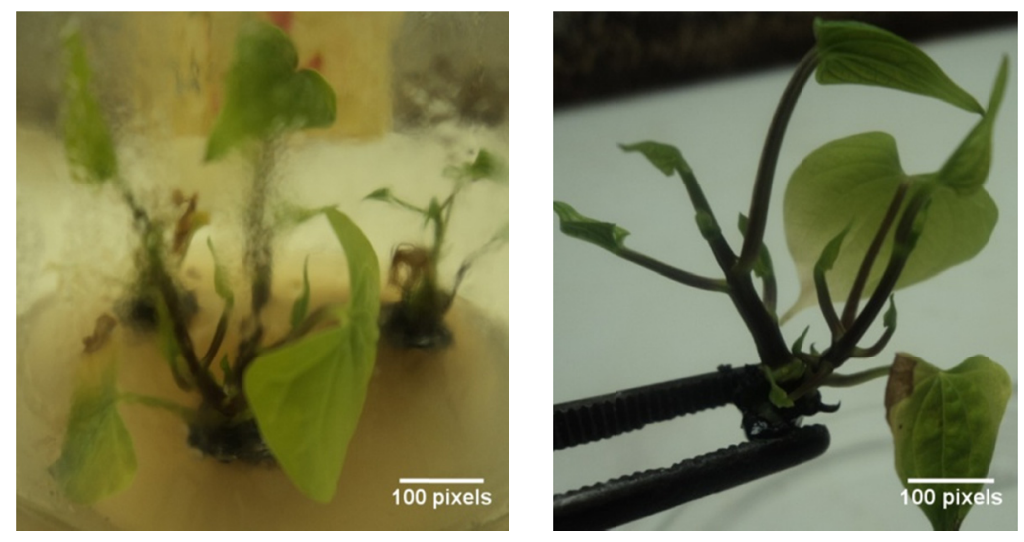

A
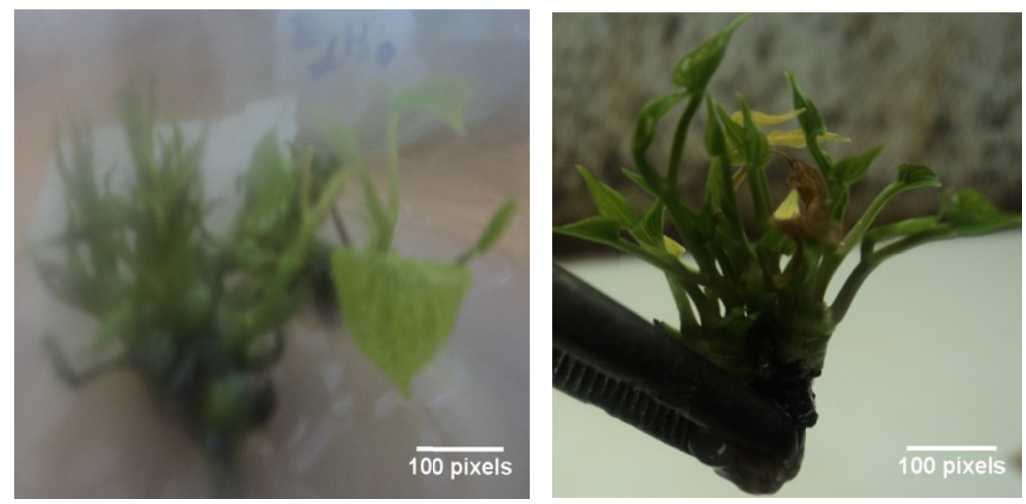

B
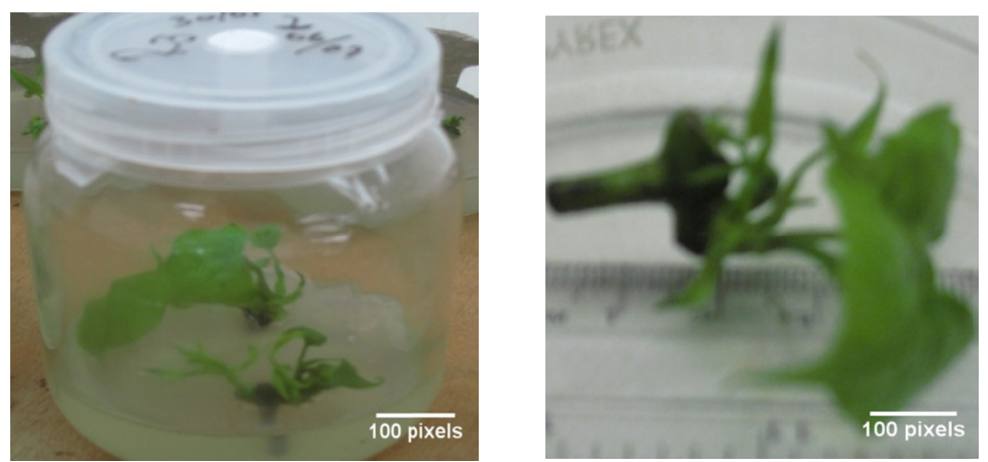

$\mathrm{C}$

Figure 3. Shoot multiplication when it is inside and out of the jar. MS medium $+1.5 \mathrm{mgl}^{-1}$ $\mathrm{BAP}+0.25 \mathrm{mgl}^{-1} \mathrm{NAA}(\mathrm{A}) . \mathrm{MS}+1.5 \mathrm{mgl}^{-1} \mathrm{BAP}+0.15 \mathrm{mgl}^{-1} \mathrm{NAA}(\mathrm{B}) . \mathrm{MS}+1 \mathrm{mgl}^{-1} \mathrm{BAP}$ $+0.15 \mathrm{mgl}^{-1} \mathrm{NAA}(\mathrm{C})$

In other reports a combination of single cytokinin with auxin was needed for better production of multiple shoots. Behera et al. (2008) reported that BAP $\left(2.0 \mathrm{mgl}^{-1}\right)+$ NAA $(0.5$ $\mathrm{mgl}^{-1}$ ) with $100 \mathrm{mgl}^{-1}$ ascorbic acid, producing an average of $6 \pm 0.18$ shoot lets per explants. They also reported that the second best shoot multiplication $(4.5 \pm 0.12)$ on a medium supplemented with BAP $\left(1.5 \mathrm{mgl}^{-1}\right)+\mathrm{NAA}\left(0.5 \mathrm{mgl}^{-1}\right)+100 \mathrm{mg}^{-1}$ ascorbic. Similarly 


\section{Macrothink}

Thankappan and Patell (2011) reported highest rate of multiplication on media with $0.5 \mathrm{mgl}^{-1}$ BAP and $0.01 \mathrm{mgl}^{-1} \mathrm{NAA}$ which was the only hormone combination they have used. Yan et al. (2011) obtained 5.5 shoots per explant on $1.0 \mathrm{mg} \mathrm{l}^{-1} \mathrm{BAP}+0.1 \mathrm{mg}^{-1} \mathrm{NAA}+30 \mathrm{~g} \mathrm{l}^{-1}$ sucrose in liquid culture which is in agreement with the second best result of this study.

\subsection{Effect of NAA and IBA Combination on Rooting}

Analysis of variance showed that there was highly significant difference between treatments $(\mathrm{p}<0.0001)$ for rooting (Appendix 2). There was also highly significant interaction between NAA and IBA. The rooting responses of shoots on different media, including mean number of roots/shoot and mean root length over a period of four weeks were significantly different (Table 2). There was no rooting in case of shoots planted on auxin free (basal) medium (Figure $4 \mathrm{C}$; Table 2). Similarly, at lower level of NAA $\left(0.5 \mathrm{mgl}^{-1}\right)$ there was hardly any rooting in the cultured shoots during the four weeks of observation period. However as shown in Table 2 higher concentration of NAA (1.5 and $\left.2.0 \mathrm{mgl}^{-1}\right)$ and IBA at some concentration tested responded well.

Rooting was best on cultures which had combinations of $1 / 2 \mathrm{MS}+2.0 \mathrm{mgl}^{-1} \mathrm{NAA}+0.5 \mathrm{mgl}^{-1}$ IBA where an average number of $5.7 \pm 0.27$ roots per plantlet and an average root length of $4.63 \pm 0.23 \mathrm{~cm}$ was recorded (Table 2, Figure 4A). The second highest rooting was recorded on $1 / 2 \mathrm{MS}+\mathrm{NAA}\left(2 \mathrm{mgl}^{-1}\right)+\operatorname{IBA}\left(0 \mathrm{mgl}^{-1}\right)$ with an average of $4.8 \pm 0.27$ roots per plantlets and an average root length of $3.52 \pm 0.20$ (Figure 4B). As shown in Table.2 NAA*IBA was more effective than their separate effects on rooting. 


\section{Macrothink Institute ${ }^{T M}$}
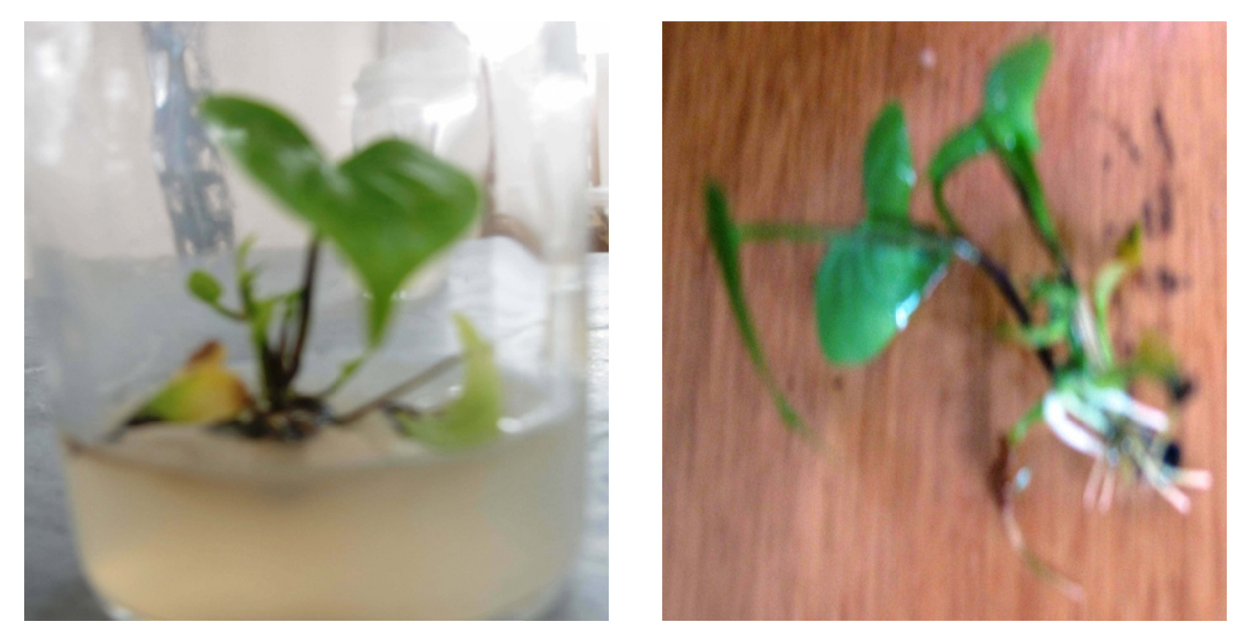

A
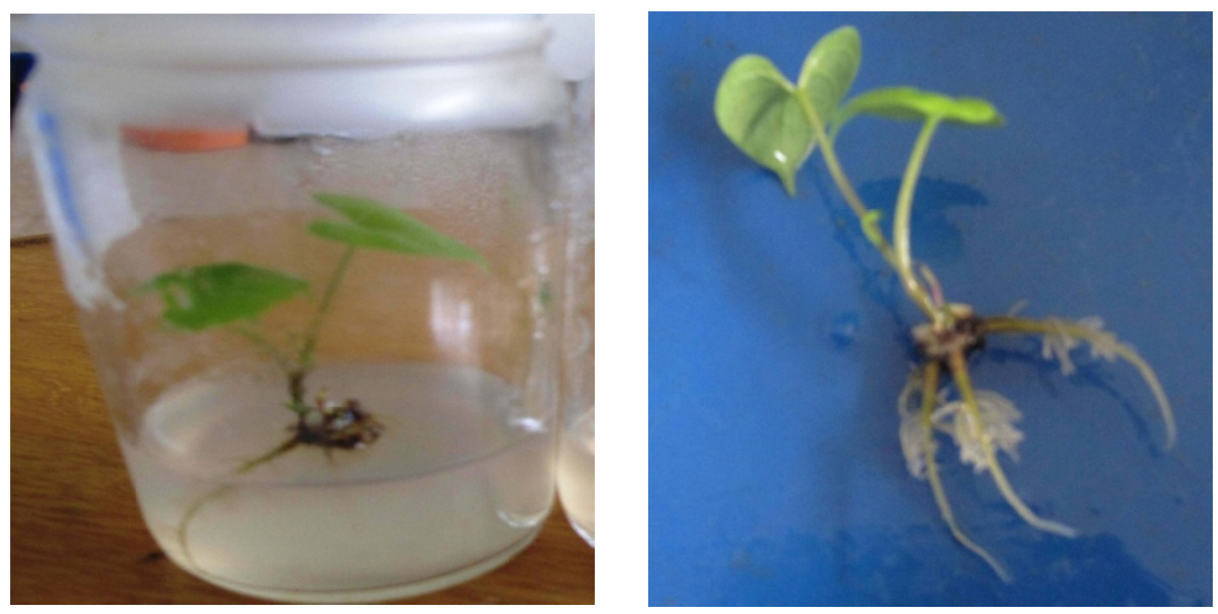

B
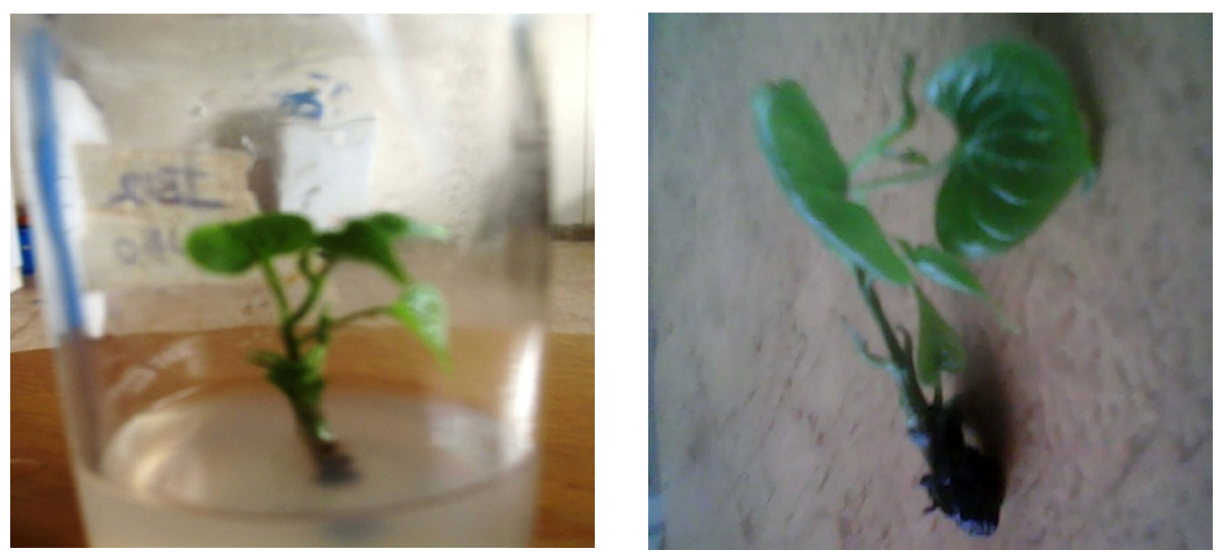

$\mathrm{C}$

Figure 4. In vitro developed roots when it is in and outside of the jar. 1/2 MS medium supplemented with $2 \mathrm{mgl}^{-1} \mathrm{NAA}+0.5 \mathrm{mgl}^{-1} \mathrm{IBA}(\mathrm{A})$. Half $\mathrm{MS}+2 \mathrm{mgl}^{-1} \mathrm{NAA}+0 \mathrm{mgl}^{-1} \mathrm{IBA}$ (B). Control (i.e. NAA \&IBA at zero level) (C) 


\section{1) Macrothink}

Table 2. Influence of different combination of NAA and IBA on rooting of in vitro generated shoot lets of Dioscorea spp. (Aw- 004/00)

\begin{tabular}{|c|c|c|c|}
\hline \multicolumn{2}{|c|}{$\begin{array}{l}\text { Plant growth regulators } \\
\left(\mathrm{mg}^{-1}\right)\end{array}$} & \multirow[t]{2}{*}{ Mean numbers of root $/$ shoot \pm S.D } & \multirow[t]{2}{*}{$\begin{array}{l}\text { Mean root length }(\mathrm{cm}) \\
\pm \text { S.D }\end{array}$} \\
\hline NAA & IBA & & \\
\hline 0 & 0 & $0.00^{1} \pm 0.00$ & $0.00^{\circ} \pm 0.00$ \\
\hline 0 & 0.5 & $0.45(1.8)^{\mathrm{hij}} \pm 0.04$ & $0.84^{\mathrm{n}} \pm 0.09$ \\
\hline 0 & 1 & $0.45(1.8)^{\mathrm{hij}} \pm 0.04$ & $0.92^{\mathrm{nm}} \pm 0.04$ \\
\hline 0 & 1.5 & $0.57(2.7)^{\mathrm{efg}} \pm 0.03$ & $1.09^{\mathrm{k} \| \mathrm{m}} \pm 0.03$ \\
\hline 0 & 2 & $0.5(2.2)^{\mathrm{ghi}} \pm 0.04$ & $1.18^{\mathrm{k} \|} \pm 0.03$ \\
\hline 0.5 & 0 & $0.23(0.7)^{\mathrm{k}} \pm 0.07$ & $0.75^{\mathrm{n}} \pm 0.03$ \\
\hline 0.5 & 0.5 & $0.43(1.7)^{\mathrm{ij}} \pm 0.04$ & $1.05^{1 \mathrm{~m}} \pm 0.09$ \\
\hline 0.5 & 1 & $0.52(2.3)^{\mathrm{fgh}} \pm 0.04$ & $1.28^{\mathrm{jk}} \pm 0.05$ \\
\hline 0.5 & 1.5 & $0.53(2.4)^{\mathrm{fg}} \pm 0.03$ & $1.42^{\mathrm{ij}} \pm 0.04$ \\
\hline 0.5 & 2 & $0.43(1.7)^{\mathrm{ij}} \pm 0.04$ & $1.29^{\mathrm{jk}} \pm 0.02$ \\
\hline 1 & 0 & $0.38(1.4)^{\dot{j}} \pm 0.04$ & $1.64^{\mathrm{gh}} \pm 0.16$ \\
\hline 1 & 0.5 & $0.5(2.2)^{\mathrm{ghi}} \pm 0.04$ & $1.74^{\mathrm{fg}} \pm 0.16$ \\
\hline 1 & 1 & $0.56(2.6)^{\mathrm{efg}} \pm 0.03$ & $1.52^{\text {hi }} \pm 0.05$ \\
\hline 1 & 1.5 & $0.58(2.8)^{\mathrm{efg}} \pm 0.03$ & $1.60^{\mathrm{ghi}} \pm 0.10$ \\
\hline 1 & 2 & $0.5(2.2)^{\mathrm{ghi}_{ \pm}} \pm 0.04$ & $1.91^{\mathrm{ef}} \pm 0.06$ \\
\hline 1.5 & 0 & $0.68(3.8)^{\mathrm{cd}} \pm 0.03$ & $1.98^{\mathrm{e}} \pm 0.06$ \\
\hline 1.5 & 0.5 & $0.72(4.3)^{b c} \pm 0.02$ & $2.90^{\mathrm{c}} \pm 0.11$ \\
\hline 1.5 & 1 & $0.63(3.3){ }^{\mathrm{de}} \pm 0.03$ & $2.40^{\mathrm{d}} \pm 0.06$ \\
\hline 1.5 & 1.5 & $0.59(2.9){ }^{\mathrm{ef}} \pm 0.03$ & $2.12^{\mathrm{e}} \pm 0.07$ \\
\hline 1.5 & 2 & $0.57(2.7)^{\mathrm{efg}} \pm 0.03$ & $1.74^{\mathrm{fg}} \pm 0.12$ \\
\hline 2 & 0 & $0.76(4.8)^{\mathrm{ab}} \pm 0.02$ & $3.52^{b /} \pm 0.20$ \\
\hline 2 & 0.5 & $0.82(5.7)^{\mathrm{a}} \pm 0.02$ & $4.63^{a} \pm 0.23$ \\
\hline 2 & 1 & $0.72(4.3)^{b c} \pm 0.02$ & $2.90^{\mathrm{c}} \pm 0.16$ \\
\hline 2 & 1.5 & $0.52(2.3)^{\mathrm{fgh}} \pm 0.04$ & $1.96^{\mathrm{e}} \pm 0.08$ \\
\hline 2 & 2 & $0.28(0.9)^{\mathrm{k}} \pm 0.06$ & $1.47^{\text {hij }} \pm 0.06$ \\
\hline $\mathrm{CV} \%$ & 6.97 & & 5.8 \\
\hline
\end{tabular}

(a-o, means having the same letter in a column were not significantly different $(\mathrm{p}<0.05)$. S.D.-Standard deviation of mean, means in the brackets is actual values while the one outside are transformed values using log transformation). 


\section{Ml Macrothink}

Production of plantlets with profuse rooting in vitro is important for successful establishment of regenerated plants in soil (Ohyam, 1970). In the present study best rooting was observed on half strength MS with NAA $\left(2.0 \mathrm{mgl}^{-1}\right)$ and IBA $\left(0.5 \mathrm{mgl}^{-1}\right)$. In this study the combinations of NAA and IBA were used but some authors suggested that auxin NAA or IBA alone is needed to profuse rooting on Dioscorea hispida (Behera et al., 2008), Dioscorea oppositifolia l. (Behera et al., 2009), Dioscorea alata (Behera et al., 2010) and reported that NAA is more effective than IBA.

On the other hand some authors reported that combination of auxin NAA and IBA was needed for better production of roots in Dioscorea prazeri (Thankappan \& Patell, 2011), Dioscorea nipponica (Chen et al., 2007) who obtained best rooting on a medium containing $1.0 \mathrm{mgl}^{-1}$ IBA and $0.5 \mathrm{mgl}^{-1} \mathrm{NAA}$ and $0.5 \mathrm{mgl}^{-1} \mathrm{IBA}$ and $0.01 \mathrm{mgl}^{-1} \mathrm{NAA}$ respectively. In addition Behera et al. (2008) reported $5.2 \pm 0.28$ roots per plantlet and an average root length of $3.5 \pm 0.12 \mathrm{~cm}$ for $D$. hispida. Behera et al. (2009) reported $6.5 \pm 0.30$ roots per plantlet and an average root length $4.5 \pm 0.16 \mathrm{~cm}$. Similarly Behera et al. (2010) obtained $5.5 \pm 0.48$ roots per plantlet and an average root length $5.2 \pm 0.26 \mathrm{~cm}$ on $1 / 2 \mathrm{MS}+2 \mathrm{mgl}^{-1}$ NAA without IBA, which is the second best in the present study.

\subsection{Acclimatization}

About $86 \%$ of the rooted plantlets exhibited establishment in the greenhouse within 3-4 weeks after being transferred to the sterilized soil medium (1:1:1 sand, forest soil and dried and decomposed manure, Figure 5). This result is almost similar with that of Behera et al., 2008; Behera et al., 2009 and Behera et al., 2010 who reported about 90\% of the rooted plantlets established in the greenhouse within 2-3 weeks of transfer on similar medium. Chen et al. (2007) also reported 91\%, survival rate of the plantlets one month after acclimatization and the young plants grew vigorously in the greenhouse.
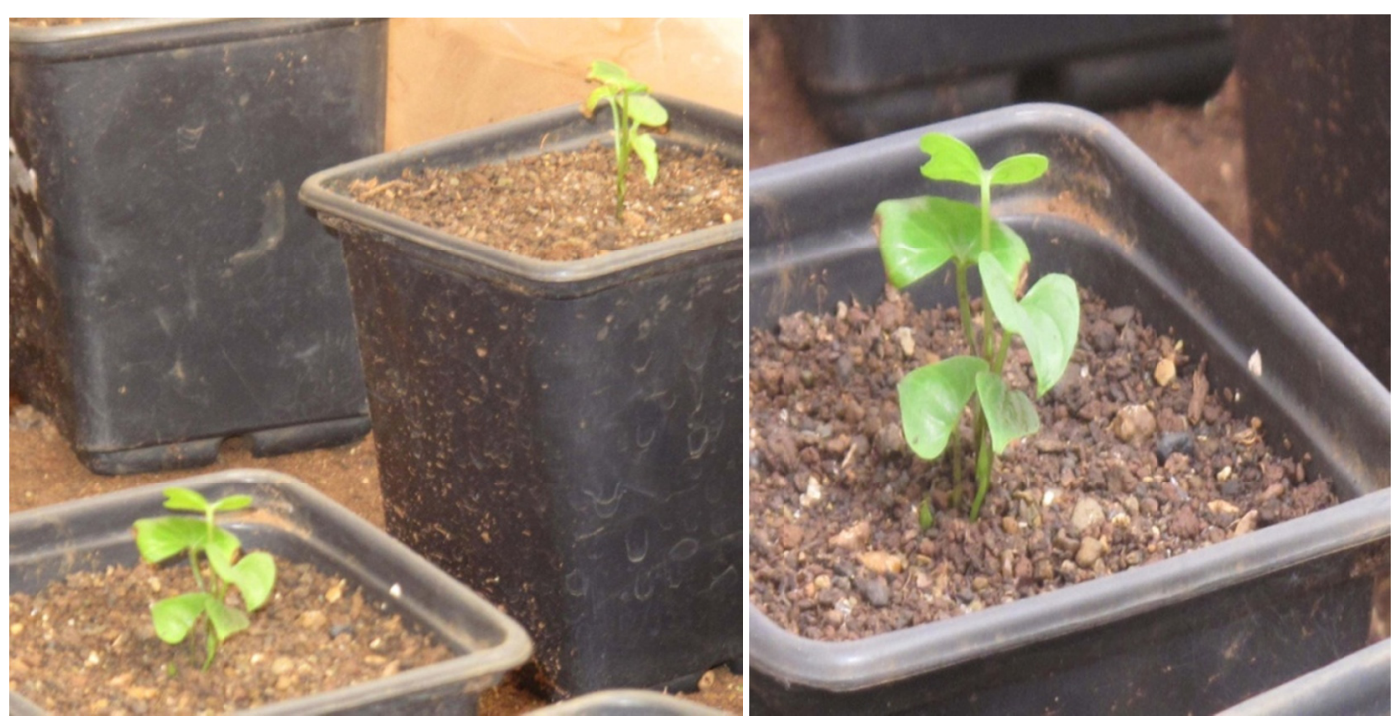

Figure 5. Plantlets after four weeks of acclimatization in the greenhouse 


\section{Macrothink}

\section{Conclusion}

From MS Medium supplemented with $1.5 \mathrm{mg} / 1 \mathrm{BAP}+0.15$ NAA $6.40 \pm 0.28$ shoot lets with a mean shoot length of $2.0 \pm 0.11 \mathrm{~cm}$ per explant was recorded and $5.40 \pm 0.28$ shoots with a mean shoot length of $1.84 \pm 0.20 \mathrm{~cm}$ from $1 \mathrm{mg} / \mathrm{l} \mathrm{BAP}+0.15$ NAA. There was no any multiplication on basal medium.

On half strength MS medium supplemented with $2 \mathrm{mg} / 1 \mathrm{NAA}+0.5 \mathrm{IBA} 5.7 \pm 0.27$ roots per plantlet and an average root length $4.63 \pm 0.23 \mathrm{~cm}$ was recorded followed by $2 \mathrm{mg} / 1 \mathrm{NAA}+0$ $\mathrm{mg} / \mathrm{l} \mathrm{IBA}$ that is almost similar to $1.5 \mathrm{mg} / 1 \mathrm{NAA}+0.5 \mathrm{mg} / \mathrm{l} \mathrm{IBA}$ where $4.8 \pm 0.27$ roots per plantlets and an average root length of $3.52 \pm 0.20$ were recorded. There is no any rooting on basal medium (medium free of plant growth regulators). In addition NAA was better than IBA for in vitro rooting of this variety. The rooted plantlets were transferred to sterilized soil for further hardening with a 1:1:1 mixture of sand, forest soil and dried and decomposed manure for further hardening. After four weeks of acclimatization $86 \%$ survival was recorded.

Generally A-w 004/00 gave 6.4 shoots per explant within 4-5 week of culturing. Thus, the optimized protocol is useful for in vitro propagation of this specific variety of yam planting material. MS media supplemented with $1.5 \mathrm{mg} / 1 \mathrm{BAP}+0.15 \mathrm{NAA}$ for shoot multiplication and $1 / 2$ MS supplemented with $2 \mathrm{mg} / \mathrm{l} \mathrm{NAA}+0.5 \mathrm{IBA}$ for rooting were the best growth regulator combinations for micropropagation of this specific variety of yam and these media combination can be recommended for further use.

\section{References}

Acha, I. A., Shiwachi, H., Asiedu, R., \& Akoroda, M. O. (2004). Effect of auxins on root development in yam (Dioscorea rotundata) vine. Tropical Science, 44, 80-84. http://dx.doi.org/10.1002/ts. 140

Adeniyi, O. J, Adetimirin, V. O, Ingelbrecht, I., \& Asiedu, R. (2008). Shoot and plantlet regeneration from meristems of Dioscorea rotundata Poir and Dioscorea alata L. African Journal of Biotechnology, 7(8), 1003-1008.

Ahanhanzo, C., Gandonou, C. B., Agbidinoukoun, A., Dansi, A., \& Agbangla, C. (2010). Effect of two cytokinins in combination with acetic acid naphthalene on yams (Dioscorea spp.) genotypes 'response to in vitro morphogenesis. African Journal of Biotechnology, 9(51), 8837-8843.

Aighewi, B. A., Asiedu, R., \& Akoroda, M. O. (2003a). Seed yam production from pre-sprouted mini-setts with varied thicknesses of storage parenchyma. African Journal of Root Tuber Crops, 5(2), 21-24.

Aighewi, B. A., Asiedu, R., \& Akoroda, M. O. (2003b). Producing seed yams (Dioscorea rotundata Poir.) from young sprouts. African Journal of Root Tuber Crops, 5(2), 13-14.

Alizadeh, S., Mantell, S. H., \& Viana, A. M. (1998). In vitro shoot culture and microtuber induction in the steroid yam Dioscorea composita Hemsl. Plant Cell, Tissue and Organ Culture, 53, 107-112. http://dx.doi.org/10.1023/A:1006036324474

Asiedu, R., \& Sartie, A. (2010). Crops that feed the World 1. Yams for income and food security. Food Science, 2, 305-315. http://dx.doi.org/10.1007/s12571-010-0085-0 
Balogun, M. O. (2009). Microtubers in yam germplasm conservation and propagation: The status, the prospects and the constraints. Biotechnology and Molecular Biology Reviews, 4(1), 001-010.

Balogun, M. O., Fawole, I., Ng, S. Y. C., Ng, N. Q., Shiwachi, H., \& Kikuno. H. (2006). Interaction among cultural factors in microtuberization of white yam (Dioscorea rotundata). Tropical Science, 46, 55-59. http://dx.doi.org/10.1002/ts.61

Balogun, M. O., Ng, S. Y. C., Shiwachi, H., Ng, N., \& Fawole, I. (2004). Comparative effects of explant sources and genotypes on microtuberization in yams (Dioscorea spp.). Tropical Science, 44, 196-200. http://dx.doi.org/10.1002/ts.168

Behera, K. K., Sahoo, S., \& Prusti, A. (2009). Regeneration of Plantlet of Water Yam (Dioscorea oppositifolia L.) through In Vitro Culture from Nodal Segments. Notulae Botanicae Horti Agrobotanici Cluj-Napoca, 37(1), 94-102.

Behera, K. K., Sahoo, S., \& Prusti, A. (2010). Micropropagation of greater yam (Dioscorea alata L.) through vine nodes. Journal of Root Crops, 36(1), 27-32.

Behera, K. K., Sahoo, S., \& Prusti, A. (2008). Effects of plant growth regulator on in vitro micropropagation of 'bitter yam' (Dioscorea hispida). International journal of integrated biology, 4(1), 50-54.

Belarmino, M. M., \& Gonzales, J. R. (2008). Somatic embryogenesis and plant regeneration in purple food yam (Dioscorea alata L.) Annals of Tropical Research, 30(2), 22-33.

Bhojwani, S, \& Razdan, M. K. (1996). Plant Tissue culture: Theory and Practice (pp. 345-355). the Netherlands: Elsevier Sceince.

Boussalem, M., Arnau, G., Hochu, I., Arnolin, R., Viader, V., Santoni, S., \& David, J. (2006). Microsatellite segregation analysis and cytogenetic evidence for tetrasomic inheritance in the American yam Dioscorea trifida and a new basic chromosome number in the Dioscoreae. Theoretical and Applied Genetics, 113, 439. http://dx.doi.org/10.1007/s00122-006-0309-z

Chen, F. Q., Fu. Y., Wang, D. L, Gao, X., \& Wang, L. (2007). The effect of plant growth regulators and sucrose on the micropropagation and microtuberization of Dioscorea nipponica Makino. Plant Growth Regulation, 26, 38-45. http://dx.doi.org/10.1007/s00344-005-0147-2

Coursey, D. G. (1967). Yams: an account of the nature, origins, cultivation and utilization of the useful members of Dioscoreaceae. (pp. 230-233). London, UK: Longmans, Greens and Co. Ltd.

Coursey, D. G. (1976). Yams, Dioscorea spp. (Dioscoreaceae) In E. D. Simmonds (Ed.) Evolution of crop plants (pp. 70-74). London: Longman.

Diehl, L. (1982). Smallholder farming systems with yam in the Southern Guinea Savannah of Nigeria (p. 340). German Agency for Technical Cooperation (GTZ).

Edwards, S. B. (1991). Crops with wild relatives found in Ethiopia. In J. M. M. Engles J. G. Hawkes \& M. Worede (Eds.), Plant Genetic resources of Ethiopia (pp. 42-74). UK: Cambridge University Press.

FAO. (2009). FAOSTAT database for 2009 Retrieved from http://www.fao.org/corp/statistics/en/ 
Feng, F., Ye, C. H., Li, Y. Z., \& Xu, W. F. (2007). Effects of growth regulators, carbon sources and photoperiod on in vitro formation and growth and development of microtubers of Dioscorea fordii. Plant Physiology short Communication, 43(6), 1045-1049.

George, E. F., \& Sherrington, P. D. (1984). Plant propagation by Tissue Culture (p. 34). Eastern Press. England.

Gamborg, O. L., Miller, R. A., \& Ojima, K. (1968). Nutrition requirements of suspension cultures of soybean root cells. Expt. Cell Res., 50, 151-158. http://dx.doi.org/10.1016/0014-4827(68)90403-5

Gemeda, A. (2000). Root and tuber crop as compliments to sustainable livelihood of the farm family in West Ethiopia. In: Agri Topia, Quarterly Newsletter of EARO, 15. Addis Ababa, Ethiopia. pp. 2-8.

George, E. F., Hall, M. A., Klerk, G-J. D. (2008). Plant propagation by tissue culture (3rd ed., volume 1) (p. 65, 115, 175). The background Published by Springer, The Netherlands.

Ghosh, S. P., Ramanujam, T., Moorthy, S. N., \& Nair, R. G. (1988). Yams. In Tuber Crops (pp. 345-351). Published by Mohan Primlani for Oxford and IBH publishing Co. Pvt.Ltd, Naraina, New Delhi, India.

Govaerts, R., Wilkin, P., \& Saunders, R. M. K. (2007).World Checklist of Dioscoreaceae, Yams and their Allies. Kew Publishing, Royal Botanic Gardens, Kew, UK.

Hahn, S. K, Osiru, D. S. O., Akoroda, M. O., \& Otoo, J. A. (1987). Yam production and its future prospects. Outlook Agric, 16, 105-110.

Hahn, S. K. (1995). Yams: Dioscorea spp. (Dioscoreaceae). In J. Smart \& N. W. Simmonds (Ed.), evolution of crop plant (pp. 112-120) London UK: Longman scientific and technical.

Hartmann, H. T., Kester, D. E., Davies, F. T., \& Geneve, R. L. (2002). Plant propagation: Principles and practices, (7th ed.) Prentice Hall. Pearson Education, Inc. New Jersey.

Hildebrand, E., Demissew, S., \& Wilkin, P. (2002). Local and regional disappearance in species of Dioscorea L. (Yams) in southwest Ethiopia. In J. R. Stepp, F. S. Wyndham \& R. R. Zarger (Eds.), Ethnobiology and biocultural diversity. Proceedings of the 7th international congress of ethno biology (pp. 678-695). University of Georgia Press, USA.

IAR (Institute of Agricultural Research). (1997). Jimma Research Centre Progress Report for the period 1996. IAR, Jimma, Ethiopia.

Kang, B. T., \& Wilson, J. E. (1981). Effect of mound size and fertilizer on white guinea yam (Dioscorea rotundata) in Southern Nigeria. Plant and Soil, 61, 319-327.

Khanna, V. K. (2003). Plant Tissue Culture Practice (pp. 13-22). New Delhi, India: Kalyani Publishers.

Kharat, S. G., Bhave, S. G., Nadkarni, H. R., Sawant, S. S., \& Bendale, V. W. (2008). Micropropagation of Lesser Yam [Dioscorea esculenta (Lour.) Burk]. Journal of Root Crops, 34(1), 65-69

Kole, C. (2011). Wild Crop Relatives: Genomic and Breeding Resources industrial crops. (pp. 71-96). Springer-Verlag Berlin Heidelberg. http://dx.doi.org/10.1007/978-3-642-21102-7

Lebot, V. (2009). Tropical root and tuber crops cassava, sweet potatoepotatoes, yams and aroids. Crop Production Science in Horticulture Series; 17; MPG books group 
Lloyd \& McCown. (1981). Commercially-feasible micropropagation of Mountain laurel, Kalmia latifolia, by use of shoot tip culture. Int. Plant Prop. Soc. Proc, 30, 421-427.

Mahesh, R., Muthuchelian, K., Maridass, M., \& Raju, G. (2010). In vitro propagation of wild yam, Dioscorea wightii through nodal cultures. International Journal of Biotechnology, 1, 111-113

Mantell, S. H., Haque, S. Q., \& Whitehall, A. P. (1978). Clonal multiplication of Dioscorea alata L. and Dioscorea rotundata, yams by tissue culture. Journal of Horticultural Science, 53, 95-98.

Manyong, V. M. (2000). Farmers' perceptions of the resource management constraints in yam-based systems. In: Project 13: improvement of yam-based systems. Annual Report 1999 (pp. 3-4). International Institute of Tropical Agriculture, Ibadan, Nigeria.

Martine, J., \& Cappadocia, M. (1991). In vitro tuberization in Dioscorea alata L. 'Brazo fuerte' and 'Florand Dioscorea abyssinica Hoch. Plant Cell Tissue Organ Culture, 26, 147-152.

Mbanaso, E. N. A., Chukwu, L. I., \& Opara, M. U. A. (2007). In vitro basal and nodal microtuberization in yam shoot cultures (Discorea rotundata poir, cv. Obiaoturugo) under nutritional stress conditions. African Journal of Biotechnology, 6(21), 2444-2446

Mie'ge, J., \& Demissew, S. (1997). Dioscoreaceae. In S. Edwards, S. Demissew, \& I. Hedberg (Eds.), Flora of Ethiopia \& Eritrea, Vol 6, Hydrocharitaceae to Araceae (pp. 55-62). Addis Ababa, Ethiopia, and Uppsala, Sweden.

MoA (Ministry of Agriculture). (2010). Animal Health and Plant Regulatory, Crop Variety Register Issue No. 13. Addis Ababa

Mulaama, E. (2004). Marugu: better than bread. Leisha Mag, 20(1), 26-27.

Mulualem, T. (2008). Morphological characterization and preliminary evaluation of aerial yam /Dioscorea bulbifera (1.)/ Accessions collected from south and southwestern Ethiopia. M.Sc. thesis, Presented to School of Graduate Studies, Hawassa University, Hawassa. p. 44, 68.

Murashige, T. (1974). Plant propagation trough tissue cultures. Annual Review of Plant Physiology, 25, 135-166. http://dx.doi.org/10.1146/annurev.pp.25.060174.001031

Murashige, T., \& Skoog, F. (1962). A revised medium for rapid growth and bioassays with tobacco tissue culture. Physiol. Plant., 15, 473-497. http://dx.doi.org/10.1111/j.1399-3054.1962.tb08052.x

Mwirigi, P. N., Kahangi, E. M., Nyende, A. B., \& Mamati, E. G. (2010). In vitro propagation of the Kenyan yam (Dioscorea spp.) African journal of horticultural science, 3, 112-122.

Nair, S. G., Abraham, K., \& Nayar, G. G. (1987).Two high yielding selections of white yam (Dioscorea rotundata Poir.). Journal of Root Crops, 2, 103- 109.

$\mathrm{Ng}$, S. Y. C. (1988). In vitro tuberization in white yam (Dioscorea rotundata). Plant Cell Tissue Organ Culture, 14, 121-128. http://dx.doi.org/10.1007/BF00041185

Nitsch, J. P., \& Nitsch, C. (1969). Haploid plants from pollen grains. Science, 163, 85-87. http://dx.doi.org/10.1126/science.163.3862.85

Ohyama, K. (1970). Tissue culture in mulberry tree. Jpn. Agric.Res.Quart., 5, 30-34. 
Okoli, O. O., Igbokwe, M. C., Ene, L. S. O., \& Nwokoye, J. U. (1982). Rapid multiplication of yam by the minisett technique. Research Bulletin 2. National Root crops research Institute, Unudike, Nigeria, p. 12.

Omar, M. S., \& Aouine, M. (2007). Commercial in vitro Mass Propagation of Plants: Current Status and Future. (pp. 94-99).

Poornima, G. N., \& Ravishankar, R. V. (2007). In vitro propagation of wild yams, Dioscorea oppositifolia (Linn) and Dioscorea pentaphylla (Linn). African Journal of Biotechnology, 6, 2348-2352.

Ramirez-Magon, R., Borodanenko, A., Barrera-Guerra, J. L, \& Ochoa Alejo, N. (2001). Shoot number and shoot size as affected by growth regulators in vitro cultures of $\begin{array}{lllll}\text { Spathyphyllum floribundum } \quad \text { L. } & \text { Scin.Horti., } & 89, & \text { 227-236. }\end{array}$ http://dx.doi.org/10.1016/S0304-4238(00)00236-3

Razdan, M. K. (2003). Introduction to plant tissue culture (2nd ed.) (pp. 234-236). USA: Science publisher, Inc.

SAS Institute Inc. (2008). SAS/STAT ® 9.2 User's Guide (pp. 78-83). Cary, NC: SAS Institute Inc Saunders.

Schenk, R. U., \& Hildebrandt, A. C. (1972). Medium and techniques for induction and growth of monocotyledonous and dicotyledonous plant cell cultures. Can. J. Bot, 50, 199-204. http://dx.doi.org/10.1139/b72-026

Shiwachi, H., Ayankanmi, T., \& Asiedu, R. (2005a). Effect of photoperiod on the development of inflorescences in white guinea yam (Dioscorea rotundata). Tropical Science, 45(3), 126-130. http://dx.doi.org/10.1002/ts.6

Shiwachi, H., Kikuno, H., \& Asiedu, R. (2005b). Mini tuber production using yam (Dioscorea rotundata) vines. Tropical Science, 45(4), 163-169. http://dx.doi.org/10.1002/ts.22

Tamiru, M. (2006). Assessing diversity in yams (Dioscorea spp.) from Ethiopia based on morphology, AFLP markers and tuber quality, and farmers' management of landraces. $\mathrm{PhD}$ thesis, Georg-August-University Goettingen, Germany. Cuvillier Verlag, Goettingen, Germany, p. 155.

Tamiru, M., Becker, H. C., \& Maass, B. L. (2007). Genetic Diversity in yam germplasm (Dioscorea spp.) from Ethiopia and their relatedness to the main cultivated Dioscorea species assessed by AFLP Markers. Crop Science (accepted). http://dx.doi.org/10.2135/cropsci2006.11.0719

Tamiru, M., Heiko, C., Becker, L., \& Maass, L. (2008). Diversity, distribution and management of yam landraces (Dioscorea spp.) In Southern Ethiopia. Genetic Resource of Crop Evolution, 55, 115-131. http://dx.doi.org/10.1007/s10722-007-9219-4

Tamiru, M., Maass, B. L., \& Becker, H. C. (2005). Traditional management and use of yams (Dioscorea spp.) in Wolayita, Southern Ethiopia. Book of abstracts, p. 433.

Thankappan, S. S., \& Patell, V. M. (2011). In vitro propagation studies and genetic fidelity assessment of endangered medicinal wild Yam- Dioscorea prazeri .Plant Omic Journal, 4(4), 177-189. 
Wang, S. J., Gao, W. Y., Liu, H. Y., Chen, H. X., Yu, J. G., \& Xiao, P. G. (2006). Studies on the physicochemical, morphological, thermal and crystalline properties of starches separated from different Dioscorea opposita. Food Chemistry, 99, 38-44. http://dx.doi.org/10.1016/j.foodchem.2005.07.007

Westphal, E. (1975). Agricultural systems in Ethiopia. Center for Agriculture Publishing and Documentation, Wageningen, the Netherlands, p. 278.

Wilkin, P. (1998). A morphometric study of Dioscorea quartiniana A. Rich (Dioscoreaceae). Kew Bulletin, 54, 1-18. http://dx.doi.org/10.2307/4111020

Wilkin, P. (2001). Dioscoreaceae of South-Central Africa. Kew Bull, 56, 361-404. http://dx.doi.org/10.2307/4110963

Wilson, J. E. (1989). Rapid Multiplication of Yams (Dioscorea spp.). IRETA Publications, Western Samoa.

Winch, T. (2006). Growing food a guide to food production (pp. 217-220). UK: Hereford.

Yan, H., Yang, L., \& Li, Y. (2011). Axillary shoot proliferation and tuberization of Dioscorea fordii Prain et Burk. Plant Cell Tissue Organ Culture, 104, 193-198. http://dx.doi.org/10.1007/s11240-010-9818-1

\section{Appendices}

Appendix 1. Mean squares for shoot growth parameters as affected by combination of BAP and NAA

\begin{tabular}{lllllll}
\hline $\begin{array}{l}\text { Source of } \\
\text { variation }\end{array}$ & DF & $\begin{array}{l}\text { Number } \\
\text { shoots/explant }\end{array}$ & $\begin{array}{l}\text { of } \\
\text { nomber } \\
\text { nodes/explant }\end{array}$ & $\begin{array}{l}\text { of } \\
\text { Number } \\
\text { leaves/shoot }\end{array}$ & $\begin{array}{l}\text { of } \\
\text { Average } \\
\text { shoot length }\end{array}$ \\
\hline BAP & 3 & $17.14 * * *$ & $33.85^{* * *}$ & $0.32605706 * * *$ & $7.1 * * *$ \\
NAA & 3 & $25.64 * * *$ & $75.65 * * *$ & $1.24430662 * * *$ & $9.8 * * *$ \\
BAP* NAA & 9 & $2.76^{* * *}$ & $4.58^{* * *}$ & $0.29455963 * * *$ & $0.89 * * *$ \\
CV (\%) & 8.3 & 6.9 & 5.4 & 9.7 \\
\hline
\end{tabular}

$* * *=$ highly significant at $\mathrm{P}<0.0001, \mathrm{P}=$ probability value, $\mathrm{MS}=$ mean square, $\mathrm{DF}=$ degree of freedom, $\mathrm{CV}=$ Coefficient of variation, $\mathrm{BAP}=6$-benzylaminopurine, $\mathrm{NAA}=$ $\alpha$-naphthalene acetic acid. 


\section{Macrothink}

Appendix 2. Mean squares for root growth parameters as affected by combination of IBA and NAA

\begin{tabular}{llll}
\hline Source of variation & DF & Number of root / shoot & Average root length \\
\hline NAA & 4 & $0.31 * * *$ & $17.38 * * *$ \\
IBA & 4 & $0.16^{* * *}$ & $2.09 * * *$ \\
NAA*IBA & 16 & $0.12^{* * *}$ & $2.09 * * *$ \\
CV $(\%)$ & & 6.97 & 5.8 \\
\hline
\end{tabular}

$* * *=$ highly significant at $\mathrm{P}<0.0001, \mathrm{P}=$ probability value, $\mathrm{MS}=$ mean square, $\mathrm{DF}=$ degree of freedom, $\mathrm{CV}=$ Coefficient of variation, $\mathrm{IBA}=$ indole-3-butyric acid, NAA $=\alpha$-naphthalene acetic acid.

\section{Copyright Disclaimer}

Copyright reserved by the author(s).

This article is an open-access article distributed under the terms and conditions of the Creative Commons Attribution license (http://creativecommons.org/licenses/by/3.0/). 